\title{
Effect of Fluoride and Bleaching Agents on the Degradation of Titanium: Literature Review
}

\author{
Gabriella MP Juanito ${ }^{1}$, Carolina S. Morsch ${ }^{1}$, César A Benfatti ${ }^{1}$, Márcio C Fredel ${ }^{2}$, Ricardo S Magini ${ }^{1}$ and Julio CM Souza ${ }^{1 *}$
}

${ }^{1}$ Center for Research on Dental Implants (CEPID), School of Dentistry (ODT), Federal University of Santa Catarina (UFSC), Florianópolis/SC, 88040-900, Brazil ${ }^{2}$ Department of Mechanical Engineering (EMC), Federal University of Santa Catarina (UFSC), Florianópolis/SC, 88040-900, Brazil

\begin{abstract}
The use of mouthwashes and dental gels containing fluorides has increased in recent years as well as the dental bleaching agents. However, such agents can be in contact with surfaces of dental restorative, prosthetic and implant systems at high concentration in the oral cavity. That can adversely affect the corrosion resistance of titanium and its alloys. The purpose of this review was to summarize the current data regarding the influence of fluoride and bleaching agents on the degradation of titanium and Ti6Al4V alloy surfaces. Books, chapters and full-text articles were identified on Medline and hand searches applying the following search items: "titanium and fluorides"; "titanium and hydrogen peroxide"; "titanium and ion release"; and "titanium and degradation". Thirty eight studies from an initial yield of 180 studies were selected. Results indicated that therapeutic substances used in dental practice such as fluoride, hydrogen and carbamide peroxides are related to corrosion and wear processes of titanium-based structures. Consequently, corrosive processes occurring on titanium lead to the release of ions and wear particles to surrounding peri-implant tissues and organs. However, the relation between ion release and inflammatory reactions into human tissues is not clear yet.
\end{abstract}

Keywords: Titanium; Hydrogen peroxide; Carbamide peroxide; Fluorides; Ion release

\section{Introduction}

Since the intensive work accomplished by Branemark [1], titanium and its alloys have been the first choice materials to fabricate dental implant systems and prosthetic infra-structures in oral rehabilitation supported by implants. Titanium and its alloys have a significant clinical performance due to their properties, such as low density around $4.5 \mathrm{~g} / \mathrm{cm}^{3}$, low elastic modulus (110-140 GPa), high mechanical strength (tensile strength around $950 \mathrm{MPa}$ ), high corrosion resistance and excellent biocompatibility $[2,3]$.

In fact, the corrosion resistance and biocompatibility of titanium and its alloys are resultant from the composition and structure of the titanium oxide film on the surface [3]. That oxide film primarily composed of $\mathrm{TiO}_{2}$ acts like a protective and compact thin barrier ranging from 2 to $20 \mathrm{~nm}$ in thickness $[1,3,4]$. This layer is also named passive film due to its low reactivity with the surrounding environment $[3,5]$. This oxide layer can reduce ion release from bulk $\mathrm{Ti}$ to the biological environment [2]. Nevertheless, the titanium oxide film can be destroyed in the presence of corrosive substances or wear in the oral cavity $[3,4,6]$.

The destruction of the titanium oxide film exposes fresh titanium to the corrosive environment leading to the degradation of titaniumbased oral structures including dental implants and frameworks $[3,7,8]$. The simultaneous degradation by wear and corrosion can significantly increase the material loss and failures of those structures [4,9-12]. Recently, several previous studies have revealed corrosion of titanium and its alloys after exposure to therapeutic agents such as fluorides and hydrogen peroxide [3,13-16]. As a result from degradation process, the release of $\mathrm{Ti}$ ions and particles from $\mathrm{CP}$-titanium or $\mathrm{Ti}, \mathrm{Al}, \mathrm{V}$ ions from titanium alloys to the surrounding tissues can stimulate an initial inflammatory response. The presence of released metallic ions and particles is considered a risk factor for the development of peri-implant inflammation $[17,18]$. Consequently, the diffusion of $\mathrm{Ti}, \mathrm{Al}, \mathrm{V}$ into the bloodstream can lead to cytotoxicity, mutagenic and or carcinogenic reactions considering previous studies in literature [18-20].
Implant-supported prostheses reveal microgaps at abutmentimplant or abutment-prosthesis connections that can accumulate corrosive substances for long-term period $[3,4,8]$. In this sense, acidic substances with high corrosive potential such as fluorides or bleaching agents can get into the micro-gaps and promote corrosion. The degradation process of titanium and its alloys after exposure to therapeutic substances is a phenomenon that needs to be clarified in order to identify the consequences of this process and the eventual detrimental effects to patients.

\section{Fluorides and corrosion of titanium}

The use of mouthwashes and dental gels containing fluorides to prevent caries and to treat tooth hypersensitivity has been increased in recent years. However, high concentration of fluorides adversely affects the corrosion resistance of titanium and its alloys [4,14,21-23]. In fact, high concentrations of fluoride in an aqueous solution promote an association between $\mathrm{H}^{+}$and $\mathrm{F}^{-}$ions forming hydrofluoric acid (HF), which is corrosive to many materials including titanium. Although $\mathrm{HF}$ is considered a weak acid, the strong reactivity of HF molecules is extremely aggressive to metallic materials, glass-ceramics or living tissue. Thus, the corrosion resistance of $\mathrm{Ti}$ and its alloys depends on the fluoride concentration and $\mathrm{pH}$ of the surrounding solution. The possibility of corrosion is accurately predicted from the relationship between $\mathrm{pH}$ and $\mathrm{F}^{-}$ions concentration as shown in the study of Nakagawa [22], whereas a linear threshold to localized corrosion at 30 ppm of HF [22,24]. The formation of HF concentration above $30 \mathrm{ppm}$

*Corresponding author: Julio CM Souza, PhD, DDS, MS, Federal University of Santa Catarina, Campus Trindade, 88040-900, Florianópolis, Brazil, Tel: +55 48 37219000; E-mail: jsouza@dem.uminho.pt

Received November 08, 2014; Accepted December 16, 2014; Published December 20, 2014

Citation: Juanito GMP, Morsch CS, Benfatti CA, Fredel MC, Magini RS, et al. (2015) Effect of Fluoride and Bleaching Agents on the Degradation of Titanium: Literature Review. Dentistry 5: 273. doi:10.4172/2161-1122.1000273

Copyright: (c) 2015 Juanito GMP, et al. This is an open-access article distributed under the terms of the Creative Commons Attribution License, which permits unrestricted use, distribution, and reproduction in any medium, provided the original author and source are credited. 
revealed to have a destructive effect on the protective titanium oxide film [22].

In an acidic environment, it is suggested that localized corrosion occurs even at lower concentrations of fluorides [22]. Localized corrosion on titanium can take place in a solution containing $452.5 \mathrm{ppm}$ $\mathrm{F}^{-}$at $\mathrm{pH} 4.2$ or in a solution containing $227 \mathrm{ppm} \mathrm{F}^{-}$at $\mathrm{pH} 3.8$. At higher $\mathrm{pH}$, low $\mathrm{F}^{-}$concentrations might not destroy the protective titanium oxide layer although can negatively affect the corrosion resistance of titanium $[22,25]$. $\mathrm{F}^{-}$ions were detected at different concentrations up to $920 \mathrm{ppm} \mathrm{F}^{-}$through the extracellular matrix in biofilms [26,27]. That can, slowly generate high $\mathrm{F}^{-}$amounts close to dental surfaces. For instance, localized corrosion on titanium surface can occur at $227 \mathrm{ppm} \mathrm{F}^{-}$and $\mathrm{pH} 3.8$ [22,23]. On the other hand, gels, varnishes or solutions including high $\mathrm{F}^{-}$content (9000-26000 ppm F-) often used for hypersensitivity treatment of natural teeth or after dental bleaching can also contact titanium-based surfaces of prosthetic structures or implant-abutment connections. For example, localized corrosion was detected on titanium surfaces in a solution containing $12300 \mathrm{ppm} \mathrm{F}^{-}$at pH 6.5 due to the pitting corrosion process [23]. Some previous studies relating the effects of fluorides on titanium are shown in Table 1.

Thus, patients who wear titanium based implant and prostheses must be informed on the negative effect of high $\mathrm{F}^{-}$concentration agents associated with acidic substances. So, it is of major importance that dentists check the clinical history of the patients in order to evaluate the presence and composition of dental implants and prostheses.

Previous studies also revealed that the chemical composition, structure and dielectric properties of titanium oxide film determine the corrosion resistance of titanium in corrosive substances [24]. A study has shown that adding $0.1-0.2 \%$ platinum $(\mathrm{Pt})$ or palladium $(\mathrm{Pd})$ in the composition of a titanium alloy cause dan effective improvement of the corrosion resistance of titanium in solutions containing up to $2 \% \mathrm{NaF}$.

\section{Effect of bleaching agents on the corrosion of titanium}

Hydrogen and carbamide peroxides are substances commonly used in dentistry as bleaching agents. Their concentrations vary between 1.5 and 35\% depending on the use; that can be applied by patients under professional guidance or by dentists in the dental office. In the dental office, bleaching agents are used at high concentrations up to $35 \%$ hydrogen peroxide. A dissociation of carbamide and hydrogen peroxide takes place in the presence of high temperature or light, similarly to what occurs in the oral cavity. That promotes an effective reaction of the bleaching agent with the surface leading to the destruction of the titanium oxide layer and titanium corrosion [28]. Higher values of roughness were revealed on titanium immersed in $35 \%$ hydrogen peroxide solutions when compared with groups immersed in $16 \%$ carbamide peroxide solutions [29]. Concerning the last study, significant surface alterations were noticed on CP-Ti compared to those on Ti6Al4V [29]. However, other studies have shown no difference between the corrosion of commercially pure titanium $(\mathrm{CP}-\mathrm{Ti})$ and Ti6Al4V alloy. Previous studies relating the effects of bleaching agents on titanium are shown in Table 1.

Gingival barriers are used to avoid contact of the bleaching agent at high content with other areas that could promote damage to the surrounding soft tissues [30]. However, bleaching agents can reach the surfaces of restorative, prosthetic and implant systems. For example, titanium-based infrastructure and abutments as well as implant connections may come into contact with those substances. Materials with lower corrosion resistance are more susceptible to degradation in environment containing such corrosive substances [13].

\section{Titanium degradation and its consequence}

The degradation of titanium-based prostheses and implants

\begin{tabular}{|c|c|c|c|}
\hline RESEARCH & ALLOY TYPES & $\begin{array}{l}\text { FLUORIDE ORBLEACHING AGENT } \\
\text { CONTENT (pH) }\end{array}$ & EFFECTS \\
\hline \multirow{3}{*}{$\begin{array}{l}\text { Souza et al. } \\
{[4,23]}\end{array}$} & \multirow{3}{*}{$\begin{array}{l}\text { CP titanium grade II, } \\
\text { Ti6Al4V }\end{array}$} & 20 ppm F (5.5) & OCP and EIS results on 0 upto 227 ppm indicated a passive film formation \\
\hline & & 30 ppm F (5.5) & $\begin{array}{l}\text { EIS and OCP results at } 12300 \mathrm{ppm} \text { indicated an increase of the chemical reactivity on } \\
\text { titanium }\end{array}$ \\
\hline & & $\begin{array}{l}227 \mathrm{ppm} \mathrm{F} \mathrm{(5.5)} \\
12300 \mathrm{ppm} \mathrm{F} \mathrm{(6.5)}\end{array}$ & $\begin{array}{l}\text { Significant increase of the weight loss up to } 227 \text { and } 12300 \text { ppm and consequently a } \\
\text { localized corrosion of titanium }\end{array}$ \\
\hline \multirow[b]{2}{*}{$\begin{array}{l}\text { Mabilleau et } \\
\text { al. [14] }\end{array}$} & \multirow[b]{2}{*}{$\mathrm{CP}$ titanium grade II } & 5000 ppm F & Corrosion of the surface was observed by SEM and AFM \\
\hline & & $\begin{array}{l}25000 \mathrm{ppm} \mathrm{F} \\
0.1 \% \mathrm{H}_{2} \mathrm{O}_{2} \\
10 \% \mathrm{H}_{2} \mathrm{O}_{2}\end{array}$ & Significant increase of $R a$ roughness occurred after immersion in the media \\
\hline \multirow{4}{*}{$\begin{array}{l}\text { Mayouf et al. } \\
{[21]}\end{array}$} & \multirow{4}{*}{$\begin{array}{l}\mathrm{Ti}-30 \mathrm{Cu}-10 \mathrm{Ag} \\
\mathrm{CP} \text { titanium grade II } \\
\mathrm{Ti}-6 \mathrm{Al}-4 \mathrm{~V}\end{array}$} & $0.01 \mathrm{M} \mathrm{NaF}(7.2)$ & $\begin{array}{l}\text { The presence of } 0.01 \text { and } 0.05 \mathrm{M} \mathrm{NaF} \text { at } \mathrm{pH} 7.2 \text { had a higher negative effect on the } \\
\text { corrosion resistance of TiCuAg than that recorded on Ti and TiAlV }\end{array}$ \\
\hline & & $0.05 \mathrm{M} \mathrm{NaF}(7.2)$ & TiAlV has a lower corrosion rate at $0,5 \mathrm{M} \mathrm{NaF}$ in comparison with $\mathrm{Ti}$ and $\mathrm{TiCuAg}$ \\
\hline & & $0.5 \mathrm{M} \mathrm{NaF}(7.2)$ & The high concentration of $\mathrm{NaF}$ had a significant effect on TiCuAg \\
\hline & & $0.01 \mathrm{M} \mathrm{NaF}(3.0)$ & At $\mathrm{pH}$ 3,TiCuAa showed a lower corrosion rate than that of $\mathrm{Ti}$ and TiAIV \\
\hline $\begin{array}{l}\text { Nakagawa et } \\
\text { al. [22] }\end{array}$ & CP titanium grade II & 90.5 to 9048 ppm F (3-7) & $\begin{array}{l}\text { Corrosion resistance of titanium was maintained in the } 2 \% \mathrm{NaF} \text { at } \mathrm{pH} \text { higher than } 6,2 \\
\text { The titanium corroded in a solution at } \mathrm{pH} \text { below } 6,2\end{array}$ \\
\hline $\begin{array}{l}\text { Nakagawa et } \\
\text { al. [24] }\end{array}$ & $\begin{array}{l}\text { CP titanium grade II } \\
\text { Ti-6Al-4V } \\
\text { Ti-6Al-7Nb } \\
\text { Ti-0.2Pd }\end{array}$ & 226 to $9048 \mathrm{ppm} F(3-7)$ & $\begin{array}{l}\text { CPTi, Ti-6AI- } 4 \mathrm{~V} \text { and Ti-6Al-7Nb alloys were easily corroded even at low fluoride } \\
\text { concentration in acidic environment } \\
\text { The corrosion resistance of Ti-0.2Pd alloy was higher }\end{array}$ \\
\hline $\begin{array}{l}\text { Nakagawa et } \\
\text { al. [25] }\end{array}$ & $\begin{array}{l}\text { CP titanium grade II } \\
\text { Ti-6Al-4V } \\
\text { Ti-6Al-7Nb } \\
\text { Ti-0.2Pd } \\
\text { Ti-0.5Pt }\end{array}$ & 226 to $2262 \mathrm{ppm} \mathrm{NaF}(5-6,5)$ & $\begin{array}{l}\mathrm{CP} \mathrm{Ti}, \mathrm{Ti}-6 \mathrm{Al}-4 \mathrm{~V} \text { and } \mathrm{Ti}-6 \mathrm{Al}-7 \mathrm{Nb} \text { alloys corroded in fluoride solutions containing } 453 \mathrm{ppm} \\
\mathrm{F} \\
\mathrm{Ti}-0.2 \mathrm{Pd} \text { and } \mathrm{Ti}-0.5 \mathrm{Pt} \text { revealed higher corrosion resistance than that recorded on the } \\
\text { other alloys }\end{array}$ \\
\hline $\begin{array}{l}\text { Faverani et al. } \\
{[30]}\end{array}$ & $\begin{array}{l}\text { CP titanium grade II } \\
\mathrm{Ti}-6 \mathrm{Al}-4 \mathrm{~V}\end{array}$ & $\begin{array}{l}16 \% \text { carbamide peroxide } \\
35 \% \text { carbamide peroxide } \\
35 \% \text { hydrogen peroxide }\end{array}$ & Bleaching agents caused significant changes on the surfaces of both materials tested \\
\hline
\end{tabular}

Table 1: Summary of previous studies reporting the effect of fluorides or bleaching agents on titanium and its alloys. 

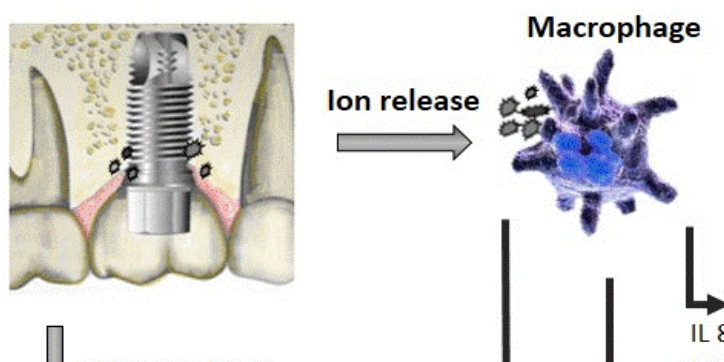

Inflammation Osteolysis Titanium degradation<smiles>c1ccccc1</smiles>
.

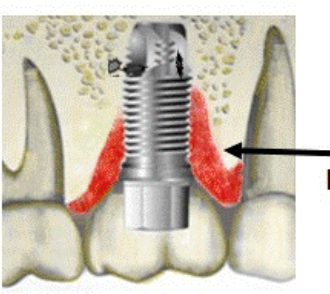

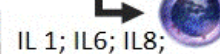

IL10; IL12; IL15

IFN- $\alpha, \beta ;$ TNF- $\alpha$

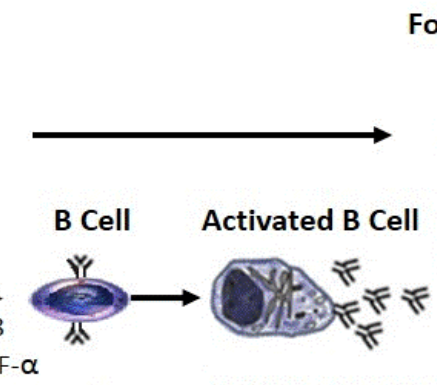

Clonal Expansion

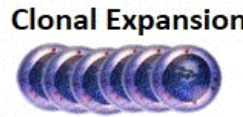

Fibroblast

IL $1 ;$ IL6; IL8; MMP-1,3; RANKL

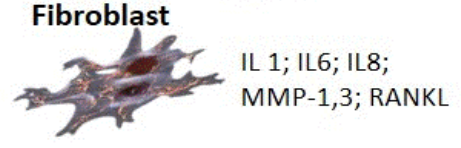

Foreign Body Giant Cell

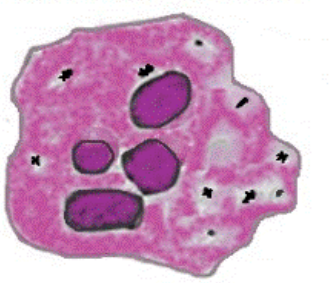

Activated TH

Lymphocyte
I S

M Y

M S

$\begin{array}{ll}U & \mathrm{~T}\end{array}$

N E

E M

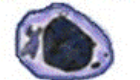

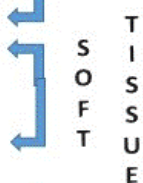

Ion release

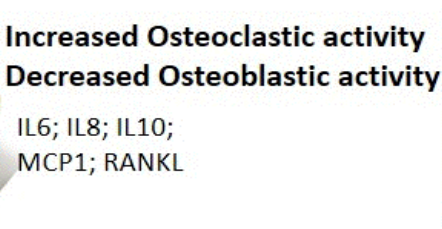

Figure 1: Schematics of titanium degradation process and ion release.

depends mainly on the conditions of the oral environment [3,31]. These conditions involve acidic $\mathrm{pH}$, presence of reactive substances, oxygen concentration and temperature. Additionally, a corrosive physiological environment in combination with cyclic loads (fatigue) and wear can significantly increase the degradation of prosthetic infrastructures and dental implant connection systems [4,5,9-12]. Thus, the destruction of the titanium oxide film exposes the fresh titanium to mechanical and electrochemical interactions increasing the degradation of the Ti-based structure [4].

The degradation of titanium can cause four main phenomena: corrosion processes affecting mechanical integrity of structural materials; change in the electrochemical reactions; increase of roughness; and release of ions [11,12]. Mechanical aspects such as forces applied, the contact geometry and type (sliding, fretting, rolling or impact) determine the corrosion rate of titanium-based structures [5].

Although titanium and its alloys show higher corrosion resistance than several metallic materials applied in oral rehabilitation, simultaneous degradation by corrosion and wear takes place resulting in corrosion products such as ions and particles. Ions and metallic particles are deposited on surrounding tissues penetrating across tissues and the bloodstream that can promote local or systemic toxicity. In previous studies, Ti particles were detected at the peri-implant tissue as well as in organs like liver, kidneys and lymph nodes [19,32,33]. On peri-implant areas, high amounts of Ti particles were detected in the surrounding bone suggesting that metallic particles were released from wear, corrosion or fatigue phenomena [19,33]. Clinically, the release of metallic ions from titanium-based structures stimulate the attraction of macrophages and $\mathrm{T}$ lymphocytes from the immune system [18,32,34-36]. High amounts of inflammatory mediators involved in bone resorption and peri-implant disease have also been associated to metallic release as illustrated in Figure $1[18,19]$.
Ions and particles composed of titanium are insoluble in physiological medium that results in high storage level and low content on the urine excretion [37]. However, aluminum and vanadium, are much more soluble leading to a high cytotoxic effect [38]. Ti6Al4V alloys used to fabricate abutments can release $\mathrm{Al}$ and $\mathrm{V}$ ions to surrounding tissues during wear, fatigue and corrosion processes [27]. Concerning the cytotoxic potential of those released metallic ions and particles, other titanium alloys have been developed to produce prosthetic structures and abutments for oral rehabilitation supported by implants.

\section{Conclusion}

Considering the literature data, dental therapeutic agents such as fluorides or hydrogen peroxide significantly influence to the degradation of titanium-based by corrosion and wear processes. The degradation rate of such structures is dependent of exposure time, $\mathrm{pH}$ and concentration of the corrosive substances. The deteriorative effect results in release of metallic ions and particles that stimulate the attraction of inflammatory cells from immune system. Such inflammatory process can be associated to peri-implant disease determining the long-term success of oral rehabilitation structures. In fact, the degradation of titanium and its alloys in the oral cavity is a phenomenon that needs to be clarified in order to prevent failures of dental implant and prostheses, to avoid eventual detrimental effects to the patients, and to improve the performance of titanium-based oral rehabilitation systems. Thus, it is of major importance that dentists check the clinical history of the patients in order to evaluate the presence and composition of dental implants and prostheses before use of fluorides or bleaching agents.

\section{References}

1. Brånemark $\mathrm{PI}$, Zarb GA, Albrektsson T (1987) Tissue Integrated Prostheses: Osseointegration in Clinical Dentistry. Quintessence Publishing Co., Chicago. 
Citation: Juanito GMP, Morsch CS, Benfatti CA, Fredel MC, Magini RS, et al. (2015) Effect of Fluoride and Bleaching Agents on the Degradation of Titanium: Literature Review. Dentistry 5: 273. doi:10.4172/2161-1122.1000273

2. Niinomi M (1998) Mechanical properties of biomedical titanium alloys. Mater Sci Eng A 243: 231-236.

3. Cruz AH, Souza JCM, Henriques M, Rocha LA (2011) Tribocorrosion and BioTribocorrosion in the oral environment: The case of dental implants. Biomedical tribology. Stanford: Nova Science Publishers 2: 1-33.

4. Souza JCM, Barbosa SL, Ariza E, Celis JP, Rocha LA (2012) Simultaneous degradation by corrosion and wear of titanium in artificial saliva containing fluorides. Wear 292-293: 82-88.

5. Landolt D (2006) Electrochemical and materials aspects of tribocorrosion systems. J Phys D: Appl Phys 39: 3121-3127.

6. Souza JC, Ponthiaux P, Henriques M, Oliveira R, Teughels W, et al. (2013) Corrosion behaviour of titanium in the presence of Streptococcus mutans. J Dent 41: 528-534.

7. Souza JC, Henriques M, Oliveira R, Teughels W, Celis JP, et al. (2010) Do oral biofilms influence the wear and corrosion behavior of titanium? Biofouling 26: 471-478.

8. Jones F (2001) Teeth and bones: applications of surface science to dental materials and related biomaterials. Surf Sci Rep 42: 75-205.

9. Lewis AC, Kilburn MR, Papageorgiou I, Allen GC, Case CP (2005) Effect of synovial fluid, phosphate-buffered saline solution, and water on the dissolution and corrosion properties of CoCrMo alloys as used in orthopedic implants. J Biomed Mater Res A 73: 456-467.

10. Brunette D, Tengvall $P$, Textor $M$, Thomsen $P$ (2001) Titanium in medicine: material science, surface science, engineering, biological responses and medical applications. Berlin: Springer.

11. Papakyriacou M, Mayer H, Pypen C, Plenk H, Stanzl-Tschegg S (2000) Effects of surface treatments on high cycle corrosion fatigue of metallic implant materials. Int J Fatigue 22: 873-886.

12. Long M, Rack HJ (1998) Titanium alloys in total joint replacement--a materials science perspective. Biomaterials 19: 1621-1639.

13. Oshida Y, Sellers CB, Mirza K, Farzin-Nia F (2005) Corrosion of dental metallic materials by dental treatment agents. Mat Sci Eng C Mater Biol Appl 25: 243348

14. Mabilleau G, Bourdon S, Joly-Guillou ML, Filmon R, Baslé MF, et al. (2006) Influence of fluoride, hydrogen peroxide and lactic acid on the corrosion resistance of commercially pure titanium. Acta Biomater 2: 121-129.

15. Fais LM, Carmello JC, Spolidorio DM, Adabo GL (2013) Streptococcus mutans adhesion to titanium after brushing with fluoride and fluoride-free toothpaste simulating 10 years of use. Int J Oral Maxillofac Implants 28: 463-469.

16. Correa CB, Pires JR, Fernandes-Filho RB, Sartori R, Vaz LG (2009) Fatigue and fluoride corrosion on Streptococcus mutans adherence to titanium-based implant/component surfaces. J Prosthodont 18: 382-387.

17. Albrektsson T, Buser D, Chen ST, Cochran D, DeBruyn H, et al. (2012) Statements from the Estepona consensus meeting on peri-implantitis, February 2-4, 2012. Clin Implant Dent Relat Res 14: 781-782.

18. Broggini N, McManus LM, Hermann JS, Medina R, Schenk RK, et al. (2006) Peri-implant inflammation defined by the implant-abutment interface. J Dent Res 85: 473-478.

19. Sjögren G, Sletten G, Dahl JE (2000) Cytotoxicity of dental alloys, metals, and ceramics assessed by millipore filter, agar overlay, and MTT tests. J Prosthet Dent 84: 229-236.

20. Wang JJ, Sanderson BJ, Wang H (2007) Cyto- and genotoxicity of ultrafine TiO2 particles in cultured human lymphoblastoid cells. Mutat Res 628: 99-106.

21. Al-Mayouf AM, Al-Swayih A, Al-Mobarak N, Al-Jabab A (2004) Corrosion behavior of a new titanium alloy for dental implant applications in fluoride media. Mater Chem Phys 86: 320-329.

22. Nakagawa M, Matsuya S, Shiraishi T, Ohta M (1999) Effect of fluoride concentration and $\mathrm{pH}$ on corrosion behavior of titanium for dental use. J Dent Res 78: 1568-1572.

23. Souza JC, Barbosa SL, Ariza EA, Henriques M, Teughels W, et al. (2015) How do titanium and Ti6Al4V corrode in fluoridated medium as found in the ora cavity? An in vitro study. Mater Sci Eng C Mater Biol Appl 47: 384-393.

24. Nakagawa M, Matsuya S, Udoh K (2001) Corrosion behavior of pure titanium and titanium alloys in fluoride-containing solutions. Dent Mater J 20: 305-314.

25. Nakagawa M, Matsuya S, Udoh K (2002) Effects of fluoride and dissolved oxygen concentrations on the corrosion behavior of pure titanium and titanium alloys. Dent Mater J 21: 83-92.

26. Ekstrand J, Oliveby A (1999) Fluoride in the oral environment. Acta Odonto Scand 57: 330-333.

27. Watson PS, Pontefract HA, Devine DA, Shore RC, Nattress BR, et al. (2005) Penetration of fluoride into natural plaque biofilms. J Dent Res 84: 451-455.

28. Chaturvedi TP (2009) An overview of the corrosion aspect of dental implants (titanium and its alloys). Indian J Dent Res 20: 91-98.

29. Al-Salehi SK, Hatton PV, Miller CA, Mcleod C, Joiner A (2006) The effect of carbamide peroxide treatment on metal ion release from dental amalgam. Dent Mater 22: 948-953.

30. Faverani LP, Barão VA, Ramalho-Ferreira G, Ferreira MB, Garcia-Júnior IR et al. (2014) Effect of bleaching agents and soft drink on titanium surface topography. J Biomed Mater Res B Appl Biomater 102: 22-30.

31. Bhattarai SR, Khalil KA, Dewidar M, Hwang PH, Yi HK, et al. (2008) Novel production method and in-vitro cell compatibility of porous Ti-6Al-4V alloy disk for hard tissue engineering. J Biomed Mater Res A 86: 289-299.

32. Kärrholm J, Frech W, Nivbrant B, Malchau H, Snorrason F, et al. (1998) Fixation and metal release from the Tifit femoral stem prosthesis. 5-year follow-up of 64 cases. Acta Orthop Scand 69: 369-378.

33. Liu Y, Xu Z, Li X (2013) Cytotoxicity of titanium dioxide nanoparticles in rat neuroglia cells. Brain Inj 27: 934-939.

34. Mjöberg B, Hellquist E, Mallmin H, Lindh U (1997) Aluminum, Alzheimer's disease and bone fragility. Acta Orthop Scand 68: 511-514

35. Jacobs JJ, Gilbert JL, Urban RM (1998) Corrosion of metal orthopaedic implants. J Bone Joint Surg Am 80: 268-282.

36. Goodman SB (2007) Wear particles, periprosthetic osteolysis and the immune system. Biomaterials 28: 5044-5048.

37. Urban RM, Jacobs JJ, Tomlinson MJ, Gavrilovic J, Black J, et al. (2000) Dissemination of wear particles to the liver, spleen, and abdominal lymph nodes of patients with hip or knee replacement. J Bone Joint Surg Am 82: 457-476.

38. Maurer AM, Merritt K, Brown SA (1994) Cellular uptake of titanium and vanadium from addition of salts or fretting corrosion in vitro. J Biomed Mater Res 28: 241-246. 